\title{
Njega wa Gioko and the European missionaries in the colonial Kenya: A theo-historical recollection and reflection
}

\begin{tabular}{|c|c|}
\hline \multicolumn{2}{|c|}{$\begin{array}{l}\text { Author: } \\
\text { Julius M. Gathogo }{ }^{1,2,3} \text { (D) }\end{array}$} \\
\hline \multicolumn{2}{|c|}{$\begin{array}{l}\text { Affiliations: } \\
{ }^{1} \text { Department of Christian } \\
\text { Spirituality, Church History } \\
\text { and Missiology, Faculty of } \\
\text { Humanities, University of } \\
\text { South Africa, Pretoria, } \\
\text { South Africa }\end{array}$} \\
\hline \multicolumn{2}{|c|}{$\begin{array}{l}{ }^{2} \text { Department of Philosophy } \\
\text { and Religious Studies, Faculty } \\
\text { of Humanities, Kenyatta } \\
\text { University, Mombasa, Kenya }\end{array}$} \\
\hline \multicolumn{2}{|c|}{$\begin{array}{l}{ }^{3} \text { Faculty of Theology, ANCCI, } \\
\text { Amarillo, TX, United States }\end{array}$} \\
\hline \multicolumn{2}{|c|}{$\begin{array}{l}\text { Corresponding author: } \\
\text { Julius Gathogo, } \\
\text { jumgathogo@gmail.com }\end{array}$} \\
\hline \multicolumn{2}{|c|}{$\begin{array}{l}\text { Dates: } \\
\text { Received: } 30 \text { Apr. } 2021 \\
\text { Accepted: } 03 \text { June } 2021 \\
\text { Published: } 12 \text { Jan. } 2022\end{array}$} \\
\hline \multicolumn{2}{|c|}{$\begin{array}{l}\text { How to cite this article: } \\
\text { Gathogo, J.M., 2022, 'Njega } \\
\text { wa Gioko and the European } \\
\text { missionaries in the colonial } \\
\text { Kenya: A theo-historical } \\
\text { recollection and reflection', } \\
\text { HTS Teologiese Studies/ } \\
\text { Theological Studies } \\
78(3), \text { a6790. https://doi. } \\
\text { org/10.4102/hts.v78i3.6790 }\end{array}$} \\
\hline \multicolumn{2}{|c|}{$\begin{array}{l}\text { Copyright: } \\
\text { C 2022. The Authors. } \\
\text { Licensee: AOSIS. This } \\
\text { is licensed under the } \\
\text { Creative Commons } \\
\text { Attribution License. }\end{array}$} \\
\hline \multicolumn{2}{|l|}{ Read online: } \\
\hline 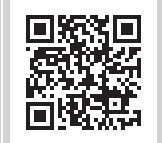 & $\begin{array}{l}\text { Scan this QR } \\
\text { code with your } \\
\text { smart phone or } \\
\text { mobile device } \\
\text { to read online. }\end{array}$ \\
\hline
\end{tabular}

Njega wa Gioko (1865-1948) was one of the pioneer Chiefs in Kirinyaga county of Kenya. The other pioneer Chief in Kirinyaga county was Gutu wa Kibetu (1860-1927) who reigned in the Eastern part of Kirinyaga county. Gioko reigned in the western part of Kirinyaga county (Ndia) that extended to some geographical parts of the present-day Nyeri county and the present-day Embu county. Njega also became the first paramount Chief of Embu district, which refers to the present-day Embu and Kirinyaga counties. As colonial hegemony and the protestant missionary enterprises, and its resultant evangelical theology, began to shape up in the present-day Kirinyaga county and the surrounding areas between 1904 and 1906, it found Gioko and Kibetu as the Athamaki (the most revered leaders). The evangelical European missionaries (Church Missionary Society [CMS]) who were comfortable with the colonial expansion, as it provided western governance structures that favoured their enterprises, employed Calvinistic theology in their dealings with the colonial government, and they dealt with the local leaders (Athamaki), who were eventually 'promoted' to the post of Chiefs in 1908 by the new rulers. Nevertheless, the missionary's emphasis on unrealised eschatology (future concerns) differed sharply with those of Athamaki who were the custodians of African indigenous religion and its resultant emphasis on realised eschatology (present concerns). As an agent of African religion, how did Gioko relate with the early 20th-century evangelical European missionaries and their Calvinistic tendencies that favoured the Church-State relationship as the way of God? The data for this research article are gathered through oral interviews, archival sources and extensive review of the relevant literature.

Contribution: This article contributes to the journal's vision and scope with its focus on the early protestant theologies of the European Missionaries of the 19th and 20th centuries, and their resultant clashes with the theologies of African indigenous religion. As a multidisciplinary article that builds on a theo-historical design, the article contributes to the ongoing discourses on gospel and culture.

Keywords: Calvinism; African Heritage; European missionaries; Athamaki and African Chiefs; Njega wa Gioko and the missionaries.

\section{Introduction}

The 19th-and 20th-century European missionaries found Njega wa Gioko (1865-1948) and Gutu wa Kibetu (1860-1927), in the present-day Kirinyaga county of Central Kenya, as the local Athamaki (plural for Muthamaki, revered elder or leader). With the Athamaki being custodians of critical matters, especially on land-related issues, they had to liaise with them in order to find places for settling their respective missionary enterprises. These European missionaries, particularly the protestant wing, were overly dismissive of African cultural lifestyles, which they felt was irredeemably ungodly, secular and fetish. They further dismissed African religiosity as ancestral worship, and its practitioners were seen as fetish worshippers (Idowu 1973:51). They also viewed the African God as a deus otiosus (idol god) or deus remotus (a withdrawn god). African religiosity was easily dismissed as: pagan, dualistic, pantheistic, animistic, idolatry, heathenism, primitivism and polytheism (Parrinder 1962:21). Nevertheless, this was nothing but the game of lexical semantics and divergent perspectives, as the indigenous people were paradoxically notorious and/or reputable in their religiosity and spirituality (Mbiti 1969:1). Interestingly, the society that was viewed as animistic or deus remotus had a strong belief in $\mathrm{Ngai}$ (God) who was well manifested in creation. Ngai or Murungu was believed to be the source of all created things, visible and invisible, and hence, the reason for another

Note: Special Collection: The World in Troubled Times: Oral History Challenges and Opportunities, sub-edited by Christina Landman (University of South Africa) and Sekgothe Mokgoatšana (University of Limpopo). 
name for God was Mumbi (moulder or creator). The African belief in God the creator resonated well with the Psalmist (24:1) who says that 'the earth is the LORD's and all there is in it'. Indigenous Africans would protect Ngai's ecology 'through myths, oral narratives, sayings, songs, dance, proverbs, taboos, riddles and drama' (Gathogo 2013:34), as they would be used to educate or caution on matters dealing with environmental preservation as a religious duty. In view of this, Gathigira (1934:29, quoted in Gathogo 2013) admits that the locals did not only conceive Ngai as an animal:

$[B]$ ut as the biggest of the animals. They also imagine him (sic) to be a human being with animal characteristics; also that he is uncharacterizable, that is to say, he cannot be described as a true human being nor as a true animal. ... Nobody has ever seen this being called Ngai and that is why, when a Gikuyu person sees something big and amazing, he exclaims, 'Truly, this object is like God!' (p. 35)

The missionaries who entered Njega wa Gioko's chiefdom also found environmental preservers who classified trees into different categories, as a measure of demonstrating their respective importance. That is (Gathogo 2013):

[B]uilding trees (refer to Mukoigo or Bridelia Micrantha); medicinal trees (refer to Mukoigo or Bridelia micrantha, Muiri or Prunus africana etc); poisonous trees (such as Rucago also called Maesopsis eminii whose dust - Muguruka - made people blind); trees that mark the boundaries (refer to Muu or Mankhaima lutea, Muigoya or Plectranthus barbatus, Kariaria or Euphorbia tirucalli also called Finger euphorbia, Mucimoro or Lantana camara etc.); trees that provided detergents for washing (refer to Muu or Mankhaima lutea); and others as sacred trees (refer to Mugumo or Ficus thoorningii, Mururi or Trichilia emetica Vahl, etc.). Some trees were regarded as sources of material culture; and one was allowed to use small trees on the fridges of the forest for purposes of making material culture items such as: farming sticks (miro), clubs (njuguma), walking sticks (mukwanju) among others, provided no human-made tools were used in the process. However, under no circumstances could one use wood from the sacred trees for house building. (p. 38)

In their holistic spirituality and religiosity that permeated all pillars of culture (refer to kinship, ethics, politics, economics, aesthetics and ethics), everyone played his or her role in service to God and the creation (Kenyatta 1938). That is, Athamaki and other leading elders were not working for themselves but for God and the community. All departments of life were driven by the theo-religious motif, as only 'good' and selfless people got promoted to the office of an ancestral spirit upon death, and hence, became mediators between the living and the dead. As a result, a departed 'good' person was remembered for generations through oral recollections. Their being 'remembered or not depended on how much good they had done on earth, especially hospitality to others' (Gathogo 2006:28). As the West African theologian, Dickson (1984) has pointed out:

In African thought those who become ancestors must have lived exemplary lives [read hospitable lives - my emphasis]; it is not everyone who dies who becomes an ancestor, so that the cult of the dead is not to be equated with that of the ancestors. (p. 198)
To this end, an emphasis on realised eschatology (present concerns) in the pre-missionary era was the key to Godliness in the African spirituality that was ironically dismissed as not there at all. To be hospitable to the immediate community, to the strangers, to the less privileged such as widows, orphans, displaced, victims of misfortunes, and the hungry, was clearly seen as the climax of African spirituality (Gathogo 2001:20-23, 2006:28). The first European explorers, missionaries and settler-farmers were initially welcomed in Njega wa Gioko's locality (Kirinyaga county of Kenya) out of this African spirituality, which expresses itself in Ubuntu (humanness), as opposed to Ubulwane or Unyama (beastly inhospitality). As discussed in this article, Muthamaki Njega wa Gioko finally employed the same African spirituality in allocating them land at the hill of Mutira (Njumbi-Mutira) in 1908. Despite this generosity, he demonstrated his dispensation of hospitality with prudence when he made it clear to both the Anglican missions (the Church Missionary Society [CMS]) and the Consolata missionaries (Roman Catholics) that 'land had to be purchased since it was not to be offered freely' (Karani 1986:31). In other words, when the Roman Catholics asked for land to settle as they opened up a centre, Gioko accepted, as in the case of the Anglicans, noted above, and allowed them to purchase the land in the then bushy and fearful Kiri-guoya area, as Kerugoya was then called. However, Kiri-guoya means the fearful place, as the forest area was filled with tough wild animals and fearful beliefs that the area had evil spirits, which was the common talk then (Njogu 2021:19). As Geoffrey Njogu (2021) has noted:

Kerugoya Town which is orally said to have been a fearful forest with tall trees and beasts before 1904-1906 when Europeans started settling in the areas now called Embu and Kirinyaga counties. Hence the name comes from the prefix kiri (the one with) and suffix guoya (the fearful). Thus Kerugoya was corrupted from Kiriguoya, meaning the fearful place. (p. 19)

Apart from hospitality as an expression of African indigenous spirituality, the European missionaries who were settling in Gioko's domain in 1907-1908 (after Colonel Richard Meinertzhagen's conquest from 1902 to 1905) found people who had their own form of medicine administration, and practitioners. Such were easily dismissed as witches, sorcerers and such related phrases (Idowu 1973:51), particularly by the protestant wing who claimed to be evangelical Christians. Indigenous medicine practitioners (Andu Ago, singular Mundu Mugo), like Athamaki, were equally powerful and/or revered people in the locality. At times, they were consulted about the future, for healing, and even for exorcising ill omens. The evil fearful spirits at Kiriguoya, now Kerugoya Town, could be exorcised from time to time by some of the medicine men and diviners. Whilst some diviners and medicine men (rarely practised by women formally and publicly, save at domestic level where prenatal and antenatal care was under them) got it through inheritance. Others got it by divine calling. They could use divination objects, common sense and also express their own insights. Characteristically, the diviners, seers, Athamaki (ideal leading elders) and fortune tellers, played priestly roles in diverse ways. 
It is no wonder that diviners are still consulted in ChristianAfrica, right into the 21st century, especially in times of crises. In times of the coronavirus disease 2019 (COVID-19), participant observation has showed that the role of African medicine men has become a critical area that is being consulted in the area that Gioko superintended. This is clearly seen as African-Christians make concoctions that seeks to treat (COVID-19). Clearly, the use of ginger, a natural antioxidant, lemon and honey as Dawa (medicine) has gained a momentum in this area where wa Gioko superintended, just as in the rest of Kenya, and is seen as one which provides COVID-19 healing properties amongst other creative ways rooted in African indigenous society. Whilst ginger is found to be critical in boosting people's health as it protects against colorectal cancer, lemon is, on the other hand, seen as rich in vitamin $C$ and critically important for detoxification. Other herbal methods of treating COVID-19 in Chief Njega wa Gioko's former jurisdiction include steam therapy or steam inhalation to fight respiratory tract infections, use of hot steam mistily wafts from a pan, use of culinary herbs and neem trees, amongst other medicinal plants. According to Rumbi Chakamba (2021:1) , a tea containing traditional Malagasy plants including Artemisia' has been used in attempting to contain COVID-19 and other related ailments in Madagascar. Although these indigenous medicinal practices, rooted in African religiosity and spirituality, have largely failed to gain traction globally, the World Health Organization (WHO) estimates that 'more than eighty percent of Africans [including wa Gioko's former jurisdiction] rely on traditional medicine for their health care needs' (Chakamba 2021:1).

With the division of labour cutting across gender divides, women, in wa Gioko's jurisdiction, made pots from Riumba, which was a special clay dug up in particular areas. These pots were largely used for storing grains, cooking, trading, carrying water amongst other religiocultural activities (Gathogo 2001:21). The protestant missionaries were keen to replace all the above 'secular' Africa's religio-cultural activities; as they failed to appreciate St. Paul as 'the proto-type of conversion in African Christianity' (Togarasei 2007:112). Certainly, St. Paul used the old religion (Judaism) to understand his new religion (Christianity). As noted in Lovemore Togarasei (2007):

The conversion of Paul is significant for Christianity in a number of ways. Indeed, for F.F. Bruce, the conversion of Paul is the second most important event in Christian history after the Christ event. Not only did it mark the beginning of Paul's Christian life, it also marked the beginning of Gentile Christianity which has seen the participation of Asians, Africans, Europeans and all in Christianity. The conversion of Paul also has provided the church with a model of conversion. On his way to persecute Christians in Damascus, Paul was suddenly turned into a Christian himself .... I argue that he had a conversion because the experience changed the direction of his life. From an ardent persecutor of the church he was turned into a passionate proclaimer of the same faith. (pp. 114-115)
Togarasei (2007) explained, thus:

The conversion of Paul changed the way Christianity was understood. Up to the time of his conversion, Christianity was understood as a Jewish sect. Paul, however, understood Christianity to be a distinct religion. As a result, he called even the Jews into this new religion. But despite this, continuity existed between Paul the Pharisee and Paul the Christian apostle. His understanding of the new religion was informed by his knowledge of the former religion. He understood himself to be worshipping the same God, even proud of his traditional roots (2 Corinthians 11:22; Philippians 3:5-6). He continued to hold Jewish scriptures in high esteem and developed his Christian theology on the basis of his Jewish background understanding, for example, the new covenant as a fulfillment of the promises of the Old Testament (1 Corinthians11:25). Indeed, scholars have observed how Paul used Jewish methods of interpreting scripture in his explication of the Christian doctrine. The use of halakah, hagaddah, typology and even allegory has been identified in his letters. (pp. 115-116)

Although the protestant missionaries had already reached the present-day Kenya in as early as 1844 when the Rev. Dr. Ludwig Krapf (1810-1881) arrived at Rabai, in the coastal city of Mombasa, only in around mid-1907, the WeithagaFort Hall CMS missionaries reached Gioko's jurisdiction. It is in 1908 when he recommended sites for missionary settlements in areas that were not 'well-developed'. Was he taking the words of a regional seer (Mugo, also called Cege wa Kibiru from the neighbouring Kariara, Murang'a near Thika Town) who had predicted the coming of the Caucasians whom he described as pale strangers and with skin complexion that would resemble pale-coloured frog that lives in water (Kiengere), prior to his death in early 1800s, and cautioned against bringing them too close to the locals? (Kenyatta 1938:71). Shortly after his death, the protestant missionaries began to enter the current Kenya's territorial space since May 1844 when the Rev. Ludwig Krapf reached Rabai. Or was Cege wa Kibiru, the Seer, reminiscing the first missionaries to settle on the East African Coast, the Portuguese Roman Catholics, who had by 1557 established monasteries at Lamu and Mombasa, a distance of over $600 \mathrm{~km}$ from his Kariara-Murang'a-Thika base? Nevertheless, it is critical to underline the nine protestant missionary societies that ushered in evangelical Christian theology that was too rigid and dogmatic. Unlike the Roman Catholics, in wa Gioko's Central Kenya region, evangelical protestant societies propounded a rigid and/or blind theological trajectory that had no room for dialogue with the local people whom they were going to evangelise. They included the (Gathogo 2010):

Gospel Missionary Society (GMS), German Lutheran Mission (GLM), Friends Africa Mission (FAM), Seventh Day Adventists (SDA), Church Missionary Society (CMS), Church of Scotland Mission (CSM), United Methodist Mission (UMM), and African Inland Mission (AIM). (p. 78)

Their dogmatic theological positions resulted in the the formation of African Instituted Churches in the region. 


\section{Calvinism in the missionary protestantism}

A critical theological perspective that informed the protestant European missionaries in the colonial Kenya is Calvinism. As a concept, Calvinism is derived from the theological works of the 16th-century protestant reformer, John Calvin (15091564), who was a counterpart of Martin Luther (1483-1546) and Huldreich Zwingli (1484-1531). The protestant missionaries of the 19th and 20th centuries did not embrace liberal and philosophical theologies, as they took Romans 13 literally, and thereby conjectured their Christian missions on submission and loyalty to the existing authorities (Gathogo 2008:43-70). This means, they consulted Chief Gioko, as early as 1908, as wa Gioko was already working for the British protectorate government which existed from 1895 to 1920, and later for the colonial government which existed from 1920 to 1963. John Calvin, in his theological discourses, described submission to civil authorities as very necessary to humanity, just as water, light and air are (Baron 1947:122). Calvin went on to view secular leaders as 'vicars and lieutenants of God whom one cannot resist without resisting God himself' (Baron 1947:123). Such fears of civil authorities, in Calvin's view, should not be linked to fear of civil punishments and sanctions, but the reverence for God. Likewise, Martin Luther went on to say that the 'secular empire cannot exist without inequality in person, that some be free and some in bondage, some masters and some subjects' (Baron 1947:123). On a positive note, Calvin influenced the growth of democracy 'because he accepted the representative principle in government of the Church and State' (Gathogo 2009:220). As God's creation, Calvin held that Church and State were meant to offer services, and hence, they should always work together in the extension of God's kingdom on earth. He, however, did not address the challenge of having a dictatorial and/or persecuting government as that of Idi Amin of Uganda, which killed Archbishop Janani Jakaliya Luwum (1922-1977) simply for speaking his mind (Gathogo 2001:87). What can we do when the government enslaves people and fails to honour God in all their political discourses? When does the Church proclaim its position, as St. Peter said (Ac 5:29): 'we must obey God rather than men'?

Such theological positions were informative in the protestant missionary theologies in the first half of the 20th century, particularly the English missions (CMS) who evangelised wa Gioko's area. With the translation of the Bible into the local African languages, especially in the second half of the twentieth century, the missionary hold on the Bible had weakened greatly, and the locals could build their own theological positions from their own introspections and exegesis. In dealing with the African chiefs, such as Njega wa Gioko and their subjects, constant clashes were bound to occur from time to time, as the missionaries saw the African life as purely secular and not religious at all. The secular tag was because it involved inhaling and smoking snuff, drinking Muratina (local brew), polygamy, dancing, material possession and too much focus on realised eschatology (present concerns) as opposed to unrealised eschatology (future heavenly pursuits). They also viewed the colonial government as the only legitimate government that God had granted, and in following Romans 13, they had a duty to be responsible citizens of the land, a citizenry that acknowledged the presence of an existing government. In particular, they consulted Chief wa Gioko amongst other leaders in the present-day Kirinyaga county, especially when they wanted to establish their respective missionary centres. In other words, it was consultation with a pinch of salt, as the broader idea was to overthrow the religiocultural status of wa Gioko's chiefdom and replace it with evangelical Christianity of the protestant missionaries and western civilisation in general.

\section{Njega wa Gioko}

Perhaps, it is important to ask: who was Njega wa Gioko? His initial name was Maingi wa Gioko (1865-1948). He was renamed Njega (meaning the Good One) wa Gioko and was also elevated as a Muthamaki (leading elder) in 1901 after several heroic strides. Firstly, he was a great swimmer who saved several people from being swept away by the erratic flooding rivers Ruthu, Rwamuthambi and even the mighty River Sagana (Tana). The latter is the longest and largest river in Kenya covering $1000 \mathrm{~km}$ from its headwaters in the Aberdare Range and Mount Kenya to the Indian Ocean (Britannica 2021:1). As noted in the Britannica (2021:1), the river is only navigable by small craft for paltry $240 \mathrm{~km}$ out of the $1000 \mathrm{~km}$ that it covers, meaning that its roughness made any swimmer who saved drowning souls to be hailed as heroic act. The locals were thus pleased with Maingi wa Gioko's strides, as they saw Ngai's omnipresence in his superhuman efforts, and hence, he became a Muthamaki in 1901. As the colonial authorities looked for the local leading Africans who could be promoted as Chiefs, Muthamaki Njega wa Gioko was the undisputed choice in Kirinyaga West of Central Kenya, particularly the Andia peoples of the present-day Kirinyaga county.

Another heroic act that led to the reverence of Maingi wa Gioko into a Muthamaki Njega wa Gioko was his triumphant stopping of John Boyes' (1875-1951) team who attempted to cross over from Mbiri (now Murang'a county) to the presentday Kirinyaga county, in mid-1901. Without superior arms, Maingi wa Gioko was able to successfully engage Boyes' team and repulsed them; hence they did not enter his jurisdiction at that time. However, Boyes was a youthful European imperialist who had settled in the neighbouring Murang'a Town (then called Mbiri settlement) in as early as 1898 (Boyes 1912:3). Because of his love for the Turtle Beans, the locals nicknamed him Karianjahi (the one who likes to eat Turtle Beans) (Gathogo 2020a:6). He subtly made the locals in the neighbouring Murang'a to think he was ritualistically initiated in their religio-culture when he married four local Kikuyu women, thereby becoming the first known European polygamist in Kenya's historiography. Apart from this proAfrican gesture, Karianjahi learnt their local language, shot 
wild animals for food and other gimmicks that brought him closer to the locals. Initially, Boyes was seen in the league of roaming European adventurers, who was interested in Ivory trade and who could at times set the locals against one another.

Boyes (1912:7) then made a weird claim that he had bought the local mount Kirinyaga (Mt. Kenya) after he gave out 10 cows to 'Chief' Wang'ombe wa Ihura, the self-styled leader of the Kikuyu nation. He also gave 10 cows to 'Chief' Olomondo of the Dorobo ethnic group (the hunters), as both the Dorobo and the Kikuyu lived together. The 'buying' of the mountain of God, the sacred square, where the smoke of sacrificial animals was believed to go, especially as rain makers prayed for rain, was a big insult to the local spirituality, as the mountain of God could not be bought by anyone. To some, it was a mockery of the African indigenous religion. To a large extent, 'this was an open declaration of war with the Gikuyu God (Ngai)', as the 'sacred mountain of Ngai (God) could not be advertised and bidders invited for sale' (Gathogo 2020a:6). In his book, King of the Wa-Kikuyu: A True Story of Travel and Adventure in Africa, Boyes (1912:10) is unapologetic for declaring himself the first Kikuyu King. In a non-centralised society that had no Kings or Chiefs, Boyes tried to usher in a new trajectory, as even the Athamaki (leading elders) did not install themselves. The community looked at their ontological significance for quite some time and made the deserving ones Athamaki. Equally, Boyes attempted to trick them to feel like he was truly a member of the local community when he created a warrior army of 5000 uniformed Mbiri-Kikuyu men in 1899 (Boyes 1912:6). In all these discourses, we can easily view it as a conflict between the indigenous religiosity and the western theo-social perspectives.

In an African society, which is $100 \%$ Ubuntu (humane and caring) and, indeed, hospitable to strangers and wanderers, as in the case of the Muhoi (beggar) or Muthoni (in-law) who are given limited cultivation and building rights, although they cannot own land (Kenyatta 1938:42), why did Maingi wa Gioko assemble his warriors to stop them in 1901? Furthermore, in a community that sees strangers as returning ancestors, where did wa Gioko place the communal hospitality, and was he hailed and/or eulogised for being inhospitable to strangers? As early as the late 1700s, the stories of brutal incoming Europeans, with their magic sticks (guns), had been told and retold in the Central Kenya region. In particular, stories concerning Arab slave traders were equally doing rounds and/or had been experienced in some parts of the Mount Kenya region, even though little capture of slaves (if any) had been experienced in wa Gioko's locality, as was the case with the present-day Embu, Tharaka-Nithi and Embu counties. Additionally, the neighbouring Mbiri (renamed Murang'a) area, where Boyes had set up his camp, had by 1898 experienced the so-called $\mathrm{Ng}^{\prime}$ aragu ya Ruraya (the European-triggered famine) that had reduced the people into 'scavengers and skeletons who ate anything palatable, including banana tree stumps (Cienja cia marigu), and hides among other things, in a desperate attempt to stay alive' (Gathogo 2020a:3). It was renamed the European famine because the incoming Europeans to Central Kenya had disrupted food preservation through granaries and farming activities. Although Bururi wa Ndia (the land with lots of food or the present-day Kirinyaga county) was not badly affected by the European famine, as was the case with her neighbours, the society had developed fears of such encounters. Hence, when Maingi wa Gioko sought to stop the strangers from crossing over river Sagana (Tana) and enter his area, it was like trying to ward off evil spirits and/or attempting to stop it from messing up the people. In other words, hospitality as a spiritual concept, in the African indigenous society, was prudently administered (Gathogo 2001:21). Thus, blind hospitality was not the norm, nor was somebody encouraged to keep off destructive strangers who were to do harm to the people. In any case, fears of returning evil spirits could also come through harmful strangers.

Another heroic act that led to the reverence of Maingi wa Gioko into a Muthamaki Njega wa Gioko was his triumphant act of saving flocks from being mauled by fierce animals. Prior to 1901, Maingi wa Gioko had also played a critical role in saving a woman and child from some Europeans who had captured them upon coming to Mbiri (now Murang'a) (Family, pers. commun., 23 January 2019). Hence, his youthfulness, that took place as European settlers began to enter central Kenya in 1898-899, was experientially informed by bad neighbourliness, especially amongst the incoming strangers. Having experienced the Arab slave traders who had reportedly captured dozens of people in the neighbouring villages and after encountering the incoming European settlers, Njega had to prepare to pursue peace and/or make peace at whatever costs. The coming of the evangelical European missionaries, later (1907-12), did not change his suspicious position.

Shortly after the 1901 Boyes-wa Gioko warrior's contest, along river Sagana, a more brutal conquest was experienced, as the sadistic and ruthless British imperialist, Colonel Richard Meinertzhagen (1878-1967), took the area by storm. Prior to this punitive attack of 1902-1904, Meinertzhagen had just replaced Francis Hall, the pioneer European administrator in the present-day Murang'a county who died in 1901 some months after settling there. As Colonel Meinertzhagen moved from the present-day Murang'a county, through Njega wa Gioko's area, and towards the present-day Embu county headquarters, and where he finally established a Fort, in 1904 after a protracted war with local warriors, Meinertzhagen committed atrocities that are hard to record accurately, save for the doctored figures that he personally released in his book. Seen as the Christians conquering the African indigenous religion by force, rather than by proselytising, these attacks further created a huge mistrust between the westernisation and Christianity that nearly made wa Gioko to perennially fail to see anything good in it till 1947 when he reluctantly threw in the towel. During this 1902-1904 expedition, Meinertzhagen had also hired the 
services of over 500 Maasai Morans, as a back-up to his own army. Like John Boyes (1912) who chronicled his events through publishing a book, The King of Wa-Kikuyu, Colonel Richard Meinertzhagen (1957) also wrote his book, Kenya Diary, 1902-1906. In this book, he records his daily activities as he moved from Fort Hall (Murang'a Town, his new headquarters after replacing Francis Hall) to Embu, where he created a Fort by March 1904. He also boasts of his successful killings of about over 1000 Africans, although these were doctored figures. Certainly, these were oblivious people who simply came out of the bushes, where they were shepherding their flocks, to observe the caravan from Fort Hall (Murang'a) to Embu where they created a Fort after 2 years of conquest (by 17 March 1904) (Gathogo \& Nthukah 2019:29). Oral sources have it that as the oblivious people came out from the bushes to view Colonel Meinertzhagen's Caravan, they would be sprayed with bullets, which they initially referred to as the raining Maize, only to discover that it was a 'deadly

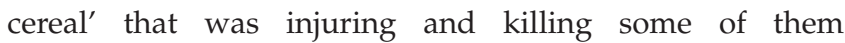
(M. Kamakia, pers. commun., 23 June 2021). After Meinertzhagen left the central region of Kenya, after the capture of Embu on 17 March 1904, and having killed about 796 people from Ndia-Gichugu (presently Kirinyaga county) and 250 from Embu-Mbeere, he went on with his brutal expeditions. In these expeditions, he travelled to Nandi where he cunningly invited Orkoiyot Koitalel Arap Samoei (1860-1905), the Supreme leader of the Nandi Nation of Kenya, to negotiate a truce on 19 October 1905, but killed him instead. This sadistic killing led to his 'deportation' out of Kenya (by early 1906), only to return quietly in 1956, 11 years before he died (Gathogo \& Nthukah 2019:41).

Based on these unfortunate backgrounds that confronted wa Gioko's childhood and youthful life, he was not able to trust the European missionary theologies that emphasised on unrealised eschatology (future heavenly hope) and co-operation with the colonial state as the way of God (Rm 13). As a colonial administrator, wa Gioko, like other colonial appointees, his duties were not just collecting hut tax and poll tax but also instructing to aid the missionaries, as they settled down in the Kenyan colony. In her book, By the Equator's Snowy Peak, Emily Crawford, wife to Dr. Crawford the missionary medical doctor at Kigari-Embu, cites the case of the erstwhile Provincial Commissioner of the Kenya Province of the then British East Africa (referring to both Kenya and Uganda which were British Protectorates), C.R.W. Lane, who on 02 December 1912 instructed Chiefs to stop interfering with the work of the European Missionaries. This letter was, however, drafted by Lane after some Chiefs started fearing the influence of missionary on their subjects (Gathogo \& Nthukah 2019:140). To this effect, African Chiefs had stopped their subjects from consuming western medicine and western religion.

Emily May Crawford cites the case of Chief Gutu wa Kibetu of the present-day Kirinyaga county, Njega wa Gioko's counterpart in the present -day Kirinyaga county, who, despite being treated with modern medicine twice by Dr. Crawford (her husband), a medical missionary based in
Kigari in Embu county, still rioted against the CMS team after recovery (Crawford 1913:150-152). Perhaps, it is worthwhile to recall that Kirinyaga county, Gioko's jurisdiction, neighbours Embu county on the eastern side and Murang'a-Nyeri on the western side. All these counties were served under the same colonial administrators who appointed African Chiefs, such as Munyiri wa Kanuku of Mavuria-Mbeere, Kombo wa Munyiri (son of Chief Munyiri wa Kanuku), Njega wa Gioko of Ndia-Kirinyaga, Gutu wa Kibetu of Gichugu-Kirinyaga, Mwandiko of Evurore-Mbeere, Kenani wa Murumbi of Evurore-Mbeere, Rumbia wa Ngotho of Nthawa-Mbeere, Manunga wa Ngoci of Nthawa-Mbeere, Njagi wa Muthang'ato of Ngandori-Embu, Wangu-waMakeri of Koimbi-Weithaga-Murang'a, Karuri wa Gakure of Weithaga-Murang'a and Kinyanjui wa Gathirimu of RirutaKiambu county. Although originally from Kiria in KandaraMurang'a, Kinyanjui Wanugu wa Gathirimu (1865-1929) was the first one to be appointed in the Mount Kenya region following the brutal killing of the 'defiant' Muthamaki Waiyaki wa Hinga in 1892 (Gathogo \& Nthukah 2019:141).

The defiance of Gioko and Kibetu against western medicine, western foods and western education resulted in painful encounters that inculcated mistrust in their dealings with all Europeans, who largely looked the same. Such mistrusts went a notch higher when Harry Thuku (1895-1970), a leading nationalist who is comparable with South Africa's Albert Luthuli (1898-1967), formed a political party (Young Kikuyu Association) in 1921. This irked the colonial authorities, as the young Thuku followers were causing trouble. It was decided that Thuku was to be drowned at Chania Falls, near Blue Post Hotel in Thika. In this incident, all the regional Chiefs under Kinyanjui were Gathirimu (1865-1929) 'agreed' with that suggestion. Paradoxically, Njega wa Gioko was the only Chief who stubbornly refused to sign, and thereby allow the colonial authorities to have their way out and eventually drown the pioneer Kenyan nationalist to death (Gathogo \& Nthukah 2019:126). According to Waruhiu Itote (1979:2), the colonial government was annoyed of Thuku who had sent a Telegram to a Senior British Minister, exposing the difficulties that Africans were going through. It included land expropriation and forced labour. For exposing the nakedness of the King, Thuku and his group were to be thrown in the rapids (ndia or ndurumo) of the mighty river Chania (Itote 1979:3). As noted in Gathogo (2020b):

As the huge crowd gathered to listen to Chief Kinyanjui [wa Gathirimu], as he explained why Thuku, the rabble-rouser, and his team, should be drowned via river Chania, Chief Njega wa Gioko, of the present day Kirinyaga County shot up, in his usual commanding voice, 'Nie Njega wa Gioko, nindarega Thuku akue niundu wa kuga woni wake', that is, 'I Njega, son of Gioko, I refuse to surrender Thuku to death, for speaking his mind'. After which, the crowd got worked up in support of this, a phenomenon that precipitated the meeting to die prematurely. (pp. 5-6)

Such defiance was not simply a political protest but a holistic rebuttal of all what colonialism and its religious inclinations stood for. Although Thuku was finally deported to Kismayu, in the then British Somaliland, and not drowned to death via river Chania (Itote 1979:4), Njega wa Gioko could not understand how the religious practice that was meant to 
replace his people's religion could be blind to such bizarre forms of punishment. Put it differently, wa Gioko could have been wondering how Church-State relationship meant (Calvinism). In other words, are all decisions made by an established government sound? It is no wonder that despite being a Civil Servant, wa Gioko associated himself with all other Chiefs who were against European Settlers. He also joined all the political associations that were formed by the African nationalists during his lifetimes. This included the Young Kikuyu Association (YKA 1921), the Kikuyu Central Association (KCA 1925) and the more national party, the Kenya African Union (KAU 1946). He also took the KAU oath of obedience and commitment to the freedom struggle despite his position in government (Karani 1986:28). Wasn't it an extremist position and/or unnecessary risk?

Whilst it is easy to discuss the extremism of the evangelical European missionaries as they attempted to assert the superiority of Christianity, which was clothed in western garments, it is equally imperative to underline the extremism of the African context as well. In the case of Njega wa Gioko, his unfortunate encounter with the early settlers and colonial functionaries could certainly have promoted a permanent mistrust. Nevertheless, his failure to listen and learn new things from these 'strange Caucasians' can equally be seen as an extreme position. In an interview with an eye witness, Mwalimu A. Murage (pers. commun., 13 April 2016), the son of Hezekiah Ngigi Ngari - the pioneer African medical practitioner in the old Embu district (which now has Kirinyaga and Embu counties), the researcher gathered the extremity of wa Gioko in diverse ways. Firstly, he would mock every aspect that came with the evangelical missionaries, including the use of cups and plates, as he equated them with skulls of dead people. He could equate school-goers with lazy people and/or parasites, as there were lots of farming and shepherding activities that he felt could be carried out instead. Before his Damascun-like conversion, where he finally embraced modernity (Church and school), he could not even carry a handkerchief as he wondered why a sane person could keep dirty mucus in his or her pockets amongst other extremist positions (Karani 1986:26-27). At a Nyeri meeting that was convened by the Provincial Commissioner (PC), he lashed out at the European District Commissioner (DC) who told him that he 'should buy a handkerchief' as it is 'for civilised people like you', thus (Karani 1986):

Bwana [Sir], I cannot use a handkerchief like you. You whites are fools because you keep mucus inside your pockets for days and even months just the way rats piss in one place. (p. 26)

The DC's 'provocation' came after he noted, from a couple of meetings, that wa Gioko was always walking out whenever he wanted to blow his nose; hence, the initial question: '[d]o you walk out just to blow your nose with your hands?' By refusing dialogue, wa Gioko too behaved like the Calvinistic evangelical missionaries who were overly dismissive of African patterns of living and were downright dogmatic.

Secondly, he rejected western education and religion (Christianity) with all his energy, and sometimes harassed those around him who pursued the western route; yet he ironically provided land for its progress. Thirdly, he opposed the western ways, yet he largely made use of it so as to remain at the top of things. For instance, he had a gun used for killing cattle so as to feed his large family of 80 wives, although scattered all over Ndia, Mwea and some parts of the presentday Mbeere South sub-county. He also bought a car, named Watuke, in 1945, which was used by his son Richard Njega after he abandoned his driver's job with the East African Breweries company. With this car, Richard Njega was shuttling people from the rural to the capital city of Nairobi. He also used a Stallion Horse to crisscross his vast area that he superintended, which extended to some parts of the presentday Mukurwe-ini Nyeri and the present-day Mbeere SouthEmbu county. With huge herds of sheep, goats, cattle and servants, Njega wa Gioko came out like a modern capitalist and/or western capitalist. Hence, his opposition to the western science, education and religion did not fully match. It is no wonder that a year before he died (1947), he took all people by surprise when he went to a local Kiamuthambi or Kanyeki-ini Church whilst holding a pen and a paper, and then went on to make a short speech thus, 'I son of Gioko, have allowed my people to use a pen as a spear and paper as shield' (Karani 1986:31). In my view, it is after wa Gioko's pronouncement of 1947 that Christianity and western education gained broad acceptance amongst the people of Kirinyaga West, who were eagerly awaiting wa Gioko's direction in religio-social matters. Certainly, the role of a leader in a communalistic society cannot be understated. This is compared with King Afonso 1(14561543) of the Kingdom of Kongo whom the Portuguese converted to the Roman Catholic faith only for the entire kingdom to confess new faith. As noted in Gathogo (2020c), this was actualised shortly after, as:

[T]he Kongolese aristocracy leaders adopted Portuguese titles, coats of arms, dress styles and their new names. Additionally, some middle-aged members of the kingdom were sent to Portugal to acquire the western education. Further, the Kongolese now observed Christian festivals, opened up churches, as craftsmen made Christian artefacts that were later found by missionaries of the 19th century. (p. 11)

Finally appreciating the pen as the new spear and paper as the first-hand shield in the post-missionary world, wa Gioko was able to read the future rather than embracing denialism in his daily discourses. It might have been a belated move but a necessary move, as it provided the way forward in a community where converting the King is tantamount to converting the whole kingdom. By delaying a lot in appreciating the power of the 'new normal', Njega wa Gioko failed to appreciate the 'rapid revolution' that had swept the neighbouring Mathira people of Nyeri county, in as early as 1908, when they took western education and Christianity seriously, thereby earning a descriptive name: Mathira ma Githomo (Mathira the western schooled people), and appreciated the unstoppable tempo of change. To this end, John Mbiti thus remarked in his book, African Religions and Philosophy (1969), thus:

Without warning and without physical or psychological preparation, Africa has been invaded by a world revolution. Now a new and rapid rhythm is beating from the drums of 
science and technology, modern communications and mass media, schools and universities, cities and towns. Nothing can halt this rhythm or slow down its rapid tempo. The man (sic) of Africa must get up and dance, for better or for worse, on the arena of world drama. His (sic) image of himself (sic) and of the universe is disrupted and must make room for the changing 'universal' and not simply 'tribal' man (sic). (p. 216)

Concerning the return of Christianity in the midst of the rapid rhythms of westernisation, Mbiti (1969) went on to say:

Christianity from western Europe and north America has come to Africa, not simply carrying the Gospel of the New Testament, but as a complex phenomenon made up of western culture, politics, science, technology, medicine, schools and new methods of conquering nature. The Gospel by its very nature is revolutionary; but Christianity in its modern return to Africa is the main carrier of all the elements of this world revolution. (p. 217)

As a result, wa Gioko, similar to the protestant missionaries in his area, missed an opportunity by sticking to his extreme position against the gospel. By rejecting dialogue on both sides of the divides, it denied the locals a chance to make broad comparisons in good time. It is no wonder that Njega's Kirinyaga West (Ndia) area had one of the highest levels of illiteracy in the central Kenya region by late 1940s and 1950s. And even after the 1960s when illiteracy was being conquered via basic education, the area still retained the so-called Andu Akubiba (people who did menial duties in the Kenyan cities, as their basic education could not help them secure some more professional employment opportunities in 1960s and early 1970s) (John Mwangi, pers. commun., 02 August 2021). In the 21st century however, the area had almost eclipsed other areas in the region, on matters education, as evidenced by the posting of the best results in the country during the Kenya Certificate of Primary Education annually. The area has some of the leading professionals in the country, doctors, academics, architects, philosophers, and has also hosted some of the leading administrators in the post independent Kenya; hence, wa Gioko's 1947 decree has had a huge impact in the twenty-first century (Wanjiru 2013:91).

\section{Njega wa Gioko's troubled ancestry?}

Wa Gioko's chronicler, Joseph Karimi Karani (1986:1-5), claimed that he had Kamba and Nyeri ancestries. He goes on to explain that wa Gioko was born at Karima Ka Inya (the fourth hill) in Othaya, Nyeri county, around 1865. His mother reportedly left Othaya-Nyeri for Ndia-Kirinyaga when he was barely 7 years old. He goes on to say that wa Gioko's legitimate and/or biological father, whose actual name is unknown, died before he was mature enough to know him. Coming from a community that embraces communal spirituality however, losing one's father at an early age does not mean automatic misery and/or too much upbringing challenges, as the community was culturally bound to chip in and help such unfortunate people. Karani (1986:1) went on to argue that his mother Michere left Othaya-Nyeri in 1872 for Ndia-Kirinyaga, and it is here where she shed off her widowhood and married Gioko. Wa Gioko's mother was from the neighbouring nation, Kamba and went to Othaya for unknown reasons. When Gioko was born, his mother first gave him a Kamba name, Kioko, which later changed to Gioko after both the mother and child underwent a cleansing ritual of acceptance. After these acceptance rituals, at Othaya-Nyeri, Kioko and her mother were accepted in the local Angui clan, which they had now joined. Karani (1986:1) went on to explain that Gioko left Othaya during his adulthood and moved to Ndia-Kirinyaga, where subsequently built a permanent home at Mukanduini village, Kanyekini Ward. This is, however, problematic as the argument that Gioko left Othaya-Nyeri in his adulthood is not convincing as the chronicler also says that the 7-year-old boy and his mother Michere left Othaya-Nyeri much earlier. Michere's name was to change to Wakabia as a result of her role in brewing Marwa, a traditional liquor; for once the brew was ready, Michere would generously serve it in a horn called Kabia, and hence the nickname Wakabia. It means the one who uses the horn. In an interview with some member of the family, this Kamba or Othaya-Nyeri ancestry theory was flatly disputed.

Joseph Karani's (1986) research on Njega wa Gioko, which culminated into a book on Njega wa Gioko: The Ndia Pride, especially on Othaya-Nyeri and Kamba ancestry, is disputed by a section of his family. They insisted on paternal and maternal lineage having been from the present-day Kirinyaga county and not Othaya-Nyeri or Kambaland of Eastern Kenya at all. In an interview, on 23 January 2019, they insisted that Maingi was the given name to the firstborn son of Gioko wa Maingi, a typically Ndia-Kirinyaga child (Family, pers. commun., 23 January 2019). As is the tradition amongst the local Kirinyaga people of Central Kenya, the firstborn son is named after the paternal grandfather, and hence, Gioko wa Maingi's firstborn son was named Maingi wa Gioko, as the peoples religio-cultures dictate, and in order to keep up with the ancestral pantheons. Later on, and as noted above, he embraced the name Njega (meaning the good one) and dropped Maingi in 1901. He now became Njega wa Gioko (meaning Njega son of Gioko). Regarding his mother, Micere or Wakabia, she was the daughter of Mbui, and actually his only child. This again erases the Othaya-Nyeri theory on her parentage (Family, pers. commun., 23 January 2019). Wakabia came from an area, near Kutus Town of Kirinyaga county, as currently known. The place is referred to as Gitigi-ini, near Karia Boys' High School, 2 km from Kerugoya Town. Gitigiini is geographically situated in the present-day Inoi South Location of Kirinyaga Central. Njega wa Gioko himself was born at Mukandu-ini, Gitumbi, in the present-day Kanyekiini Ward of Kirinyaga Central Sub-county. His elder brother was called Ndanu (Family, pers. commun., 23 January 2019). It is widely thought that he also had sisters, who were not established in the course of this research.

Wa Gioko's home (Mukandu-ini) was at the far end of Gitie-Karura areas, where his office and/or working centre was located. Within the same compound, some of his wives lived in scattered houses, as well as his security detail, informers, messengers (Njama ya Cibu) were also staying there (P. Kiragu, pers. commun., 25 April 2021). As the missionaries sought wa Gioko's permission to acquire 
land for missionary settlements, they had to visit this Mukandu-ini site, which now hosts Njega Secondary School. However, CMS Gitie Primary School was first built at Gitie in 1930s and was later renamed AC Kanyeki-ini Primary School. It was transferred in 1958 to where Njega's home had been and renamed Njega Primary School in memory of the legendary Chief. Njega Intermediate School also began in 1958 at the same spot. Furthermore, CMS Karura Church was built in 1919 and is the present-day ACK St. Luke's Kiamuthambi Church (Githaka, pers. commun., 25 April 2021). It was shifted from Karura to Gitie area around 1923. This was after the cultural nationalists (the locals) in the area burnt it down, in 1920, as a measure of protesting its presence, as they did not want a Church or any other religion apart from their indigenous one. Was wa Gioko the chief inciter? Thus, they wanted to maintain their unadulterated African spirituality and its resultant rituals. Wa Gioko's office at Gitie-Karura (Mukandu-ini) near Kiamuthambi Town was a beehive of activities as people across the region booked appointments so as to meet the Muthamaki turned Chief, and who died as the Senior Chief of the entire Embu District (1933-1963), now Kirinyaga and Embu counties. He was only deputised by Chief Njagi wa Muthang'ato of Ngandori Location, Embu. When he died in 1948, Chief Njagi wa Muthang'ato replaced him as the Senior Chief of Embu District whilst Chief Kombo wa Munyiri of Mavuria, Mbeere, now deputised the latter (P. Kiragu, pers. commun., 25 April 2021). The present Njega Secondary School is the actual spot, and it is where his wellmarked grave lies since 09 July 1948.

\section{Njega wa Gioko and the colonial authorities}

When the colonialists came, they wanted to take some parts of the present-day Kirinyaga county. Wa Gioko worked hard to stop colonial advance, particularly the taking of land. Known for his strong stands and brevity in defending Mwea (Kirinyaga South) from European penetration, wa Gioko employed all tricks in the game to stop it. According to Mzee A. K. Ndumu (23 April 2021), the colonial authorities were intent on converting the massive Red Soil Mwea into a sisal plantation. And as the Mzungu (Europeans) came placing beacons on the proposed area, Wa Gioko, afraid of losing pastureland for his massive flock, sent his men (njama), which stealthily followed the white man from behind (probably at night) and removed all the beacons. The Mzungu got frustrated and gave up, managing to utilise only a small portion on the eastern side that borders Embu county, which did not suffice for long. Today, only the vegetated remainders of the sisal attest to Mzungu's endeavours.

In all these discourses, geared towards protecting Mwea, Njega wa Gioko went through hard times, which were characterised by the following setbacks:

1. He was once taken to Chania Falls (near the present-day Blue Post Hotel, Thika Town). Here, he was tortured and was expected to announce that 'Mwea belongs to the
European settlers!' Failure to do so meant that he was to be drowned through the mighty River Chania. Surprisingly, Njega stood his guns. For him, it was no retreat no surrender. Instead, he announced, 'Mwea ni wa Ndia!' Or Mwea belongs to the local people of the present day Kirinyaga county of Kenya.

2. In secret, the Europeans later sub-divided Mwea, put up boundary posts and then went for Njega wa Gioko at his Mukandu-ini-Kiamuthambi base. They implored upon him to accompany them to Mwea (Kirinyaga South) to see the demarcating beacons that they had erected. They wanted wa Gioko to sign that he had consented to the 'new' arrangement. Upon arrival in the Mwea public gathering, wa Gioko spoke in the local dialect and did not allow any translation. Conversely, wa Gioko mobilised the people to uproot the beacons that had been erected in Mwea, which annoyed the colonial administrators and settlers. They refused to take him back home and left him in the then bushy parts of Mwea, now Wang'uru Town and its environs. The aim was to see him mauled to death by the wild animals that were common in those bushes then. Surprisingly, he made it and returned to his Mukandu-ini home, near Kiamuthambi Town.

3. In 1933, Chief Kombo wa Munyiri of Mavuria location of Mbeereland, in the present-day Mbeere South Constituency, announced that, henceforth, Mwea would be part of his Mavuria location. It is important to note that Mbeereland of the present-day Embu county had three large locations following the establishment of colonial government in Kenya. That is Nthawa location (Siakago areas) under Chief Rumbia wa Ngotho, Mavuria under Kombo wa Munyiri and Ivurore location under Kenani wa Murumbi. In the case of Mavuria location, it stretches from Mwea-Kirinyaga border, Gachoka and Kiambeere. When Chief Kombo wa Munyiri announced that all Mwea stands under his jurisdiction, wa Gioko swiftly moved to the colonial court where he won the case, and even after an appeal in Nairobi, wa Gioko still won the case. It is from there that songs were composed in his praise. Nonetheless, Mwea was still sub-divided into two, as the colonial authorities employed Solomonic wisdom that Solomon himself failed to apply and divided Mwea as we see it today (Gathogo 2019b:1).

After the declaration of the State of Emergency by the then Governor of colonial Kenya, Sir Evelyn Baring, in 1952, the shy Governor who had no mercy for Mau-Mau freedom fighters, Njega wa Gioko's 'house' was scattered. Some members of wa Gioko's family were taken in diverse colonial detention camps, put in the new villagisation that came with the crackdown of Mau-Mau uprising and so on. To date, lots of challenges has been faced by the kingly family, including, ironically, destitution (Gathogo 2019b:1). To this end, Njega wa Gioko could not understand the importance of the evangelical missionary theologies that could condone the torture and harassments that he went through under the British imperialists, yet he was still working for them as their Senior Chief of the entire Embu 
district (present-day Embu and Kirinyaga counties). It is no wonder that this suspicion and mistrust saw him reluctantly accept the missionary education and religion (Christianity) only in 1947, a year before he kicked the bucket. Without structured dialogue, wa Gioko, as with the rest of the African populace, felt that gutiari muthungu na mubia (there was no marked difference between the missionary and the colonial administrator); hence, the suspicion and mistrust remained. Certainly, dialogue is critical in any human endeavour.

\section{Conclusion}

This research article set out to explore the way Chief Njega wa Gioko related with the twentieth-century European missionaries who entered his Kirinyaga West area between 1907 and 1908, particularly the evangelical protestant missionaries, the CMS. With the evangelicals employing Calvinism as their modus operandi, how did they play out their theologies on Church-State relationship? Certainly, they consulted wa Gioko as they sought to build a mission centre at Githuguya-Sagana (Sagana Technical) way back in 1907. Their unapologetic working and appreciation of the colonial government were within their Calvinistic theology, which drove them to see Church-State relations as the way of God. As the custodian of ideo-moral contents of the people, wa Gioko embraced spirituality that permeated all pillars of culture (refer to kinship, ethics, politics, economics, aesthetics and ethics), where every lifetime step was ideally a religious duty. Such holistic approaches were dismissed by the evangelicals as irreligious and the African God was seen as deus remotus or deus absconditus (a withdrawn god) who needed to be removed from the African mind, and hence, all rituals were bad. In this encounter, interfaith dialogue was the single most item that was lacking, as the duo took extremist positions. As a result, there were casualties on both sides of the divide (wa Gioko and African religio-culture versus westernisation and Christianity), as the positive aspect of 'European science' took longer before it was fully actualised in wa Gioko's Kirinyaga's jurisdiction (the western part, in particular).

As the locals burnt down CMS Karura Church (St. Luke's Kiamuthambi) in 1920, a Church built in 1919, open conflict between African religion and Christianity, that was introduced in western evangelical attire, had begun in earnest. As both sides of the divide took radical positions, the holistic growth of the society was slowed down. If the evangelical protestants sold their positive Calvinistic positions that embraced the representative principle in the government of the Church and State, it could have boosted the communal-minded African spirituality. Furthermore, if both the local Africans and the incoming Europeans appreciated the Ubuntu philosophy (where people who do not 'look like us' are seen as returning ancestors, and hence, the reason for humane treatment), then the atrocities that preceded the missionary enterprise under Richard Meinertzhagen (1878-1967), the ugly expeditions, and mistrusts could not have taken the better part of these discourses. The article has also brought the positive parts in wa Gioko versus missionaries' divergent positions, as it has underlined the significance of dialogue, rather than dogmatism, in all human endeavours.

\section{Acknowledgements}

The author wishes to thank the peer-reviewers for their thorough assessment of the article, which helped greatly in improving it.

\section{Competing interests}

The author declares that he has no financial or personal relationships that may have inappropriately influenced him in writing this research article.

\section{Author's contributions}

J.M.G. is the sole author of this research article.

\section{Ethical considerations}

This article followed all ethical standards for research without any direct contact with human or animal subjects.

\section{Funding information}

The author acknowledges the Research Institute of Religion and Theology (UNISA) for its research output that made it possible for him to complete this task.

\section{Data availability}

Data sharing is not applicable to this study as no new data were created or analysed in this article.

\section{Disclaimer}

The views and opinions expressed in this article are those of the author and do not necessarily reflect the official policy or position of any affiliated agency of the author.

\section{References}

Baron, W., 1947, Modern nationalism and religion, Harper and Brothers, New York, NY. Boyes, J., 1912, King of the Wa-Kikuyu: A true story of travel and adventure in Africa, Methuen \& Co. Ltd., London.

Britannica, 2021, 'Tana River, Kenya', Britannica: The World Standard in Knowledge Since 1768, viewed 24 April 2021, from https://www.britannica.com/place/TanaRiver-Kenya.

Chakamba, R., 2021, 'Africa's attempt to regulate traditional medicine fails to gain traction', Devex, 28 January 2021, viewed 25 June 2021, from https://www.devex. $\mathrm{com} /$ news/africa-s-attempt-to-regulate-traditional-medicine-fails-to-gaintraction-98999.

Crawford, E.M., 1913, By the equator's snowy peak: A record of medical missionary work and travel in British East Africa, Church Missionary Society, London.

Dickson, K.A., 1984, Theology in Africa, Orbis Books, New York, NY.

Gathigira, S.K., 1934, Miikarire ya Andu (Customs of the locals), Equatorial Publishers, Nairobi.

Gathogo, J., 2001, The truth about African hospitality: Is there hope for Africa?, Salt, Mombasa.

Gathogo, J., 2006, 'African hospitality: Is it compatible with the ideal Christ's hospitality?', Swedish Missiological Themes 94(1), 23-53.

Gathogo, J., 2008, 'Missionaries and colonial authorities in Kenya', Swedish Missiological Themes 96(1), 43-70. 
Gathogo, J., 2009, 'Reading John Calvin in African context: Any relevance for social reconstruction of Africa?', Studia Historiae Ecclesiasticae 34(1), 219-235.

Gathogo, J., 2010, 'The early attempts at ecumenical co-operation in East Africa: The case of Kikuyu conference of 1913', Studia Historiae Ecclesiasticae 34(2), 73-93.

Gathogo, J., 2013, 'Environmental management and African ancestral resources: Echoes from Mutira Mission, Kenya (1912-2012)', Studia Historiae Ecclesiasticae 2, 33-56.

Gathogo, J., 2019, 'Senior Chief Njega wa Gioko: Land defender with 80 wives', The Standard, 24 June 2019, viewed 30 April 2021, from https://www.standardmedia. co.ke/central/article/2001331235/senior-chief-njega-wa-gioko-land-defenderwith-80-wives.

Gathogo, J., 2020a, 'Karubiu wa Munyi and the Making of Modern Kirinyaga, Kenya', HTS Teologiese Studies 76(4), 1-8. https://doi.org/10.4102/hts.v76i4.6198

Gathogo, J., 2020b, 'Consolidating democracy in the colonial Kenya (1920-1963): Challenges and prospects', JJEOSHS 3(1), 1-18. https://doi.org/10.35544/ jjeoshs.v1i1.20

Gathogo, J., 2020c, 'Ecclesia Anglicana Conference of September 2020: Cooking Anglican ecclesiology in a Kenyan Pot?', Jumuga Journal of Education, Ora Studies, and Human Sciences Jumuga Journal of Education, Oral Studies, and Human Sciences (JJEOSHS) 3(2), 1-17. https://doi.org/10.35544/jjeoshs.v1i1.22
Gathogo, J. \& Nthukah, M., 2019, A fallow goldmine: One hundred years of Mbeere mission in Kenya, 1919-2019, Kairos, Nairobi.

Idowu, B., 1973, African traditional religion: A definition, S.C.M., London.

Itote, W., 1979, Mau Mau in action, Transafrica, Nairobi.

Karani, J., 1986, Njega wa Gioko: The Ndia Pride, Gakaara, Karatina.

Kenyatta, J., 1938, Facing mount Kenya, Heinemann, London.

Mbiti, J.S., 1969, African religions and philosophy, East African Educational Publishers, Nairobi.

Meinertzhagen, R., 1957, Kenya diary, 1902-1906, Oliver and Boyd, London.

Njogu, G., 2021, The leadership question: A critical examination of the histories of full Gospel churches of Kenya, Kairos, Nairobi.

Parrinder, G., 1962, African traditional religion, Sheldon Press, London.

Togarasei, L., 2007, 'The conversion of Paul as a proto-type of conversion in African Christianity', Swedish Missiological Themes 95(2), 111-121.

Wanjiru, J., 2013, 'Factors contributing to poor performance in Primary Schools in the Kenya Certificate of Primary Education (KCPE) in Gatundu Division, Gatundu District, Kiambu County, Kenya', Unpublished MA thesis, Kenyatta University. 